\title{
An analysis of interest in students learning of physical chemistry experiment using Scientific approach
}

\author{
Widinda Normalia Arlianty \\ Department of Chemistry Education, Islamic University of Indonesia, \\ Jl. Kaliurang km 14,5 Sleman Yogyakarta 55584, INDONESIA \\ E-mail: widindanormaliaarlianty@uii.ac.id
}

\begin{abstract}
This study was aimed to analyze interest in student learning of physical chemistry experiment on Chemistry Education students, Islamic University of Indonesia. The research was quantitative. The samples of this research were $2^{\text {nd }}-$ semester student academic year 2015. The data learning interest of students were collected by questionnaire and documentation of seven title experimental. Learning interest consisted of three indicators, concluded feeling good, attention and activity in the learning process. The results of this research showed that score mean of feeling good indicator was 25,9; score mean of attention indicator 17,8, and score mean of activity indicator 8,41 . Score Mean students for the questionnaire interest in student learning was 51,83 and this data was categorized as "good".
\end{abstract}

\section{Introduction}

Based on the results of a survey conducted by the Program for International Student Assessment (PISA) in 2012 that had been reported the field of science Indonesia students was ranked 64th out of 65 countries with an average score of 382 which is under Malaysian student with a score an average of 420, Thailand with an average score of 444, and Singapore with an average score of 551. The first rank of the survey was occupied by students from Shanghai China with an average score of 580 [1]. The survey report showed that the quality of education in Indonesia is still low, especially in science learning.

Education is process of facilities learning or acquisition of knowledge, skills, values, belief, and habbits. One effort to improve the quality of education in schools is by improving the learning process. Improving the learning process can be done by implementing various methods, models or the media that relevance with materials. The methods, models, and learning media choosen were those that triggered the students to learn by themselves throughly and seriously.

The failure of students in achieving educational goals, in general is influenced by many factors, both internal factors and external factors. Internal factors, the namely factor derived from the self-learners, for example talent, motivation to learn, interest in learning, attitude, and ability (potency). External factors are factors that come from outside the learner, for example family, learning environment, the attention to parents, educators interaction patterns, methods of learning, and so on [2].

Interest is a powerful dictator and motivator in the learning process. Students are likely to pay attention to engangein more learning activities when their interest and 
emotions are positively provoked. Learning with interest would be better than learning without interest. Interest is a tendency to seek out and participate in any learning activities. In everyday life the words of the interest and attention can not be distinguished in fact. The attention and interest do have a close relationship. Attention plays a very important in the learning process. If the learning materials delivered such that attract students' attention by it self spontaneously than learning will take place with very good. The most important thing happens in the learning process is that students are willing to learn / seek out and participate insideor outside of classroom activities to achieve Learning Outcomes set up. It is not easily arise by it self [3].

Lack of interest marked by the emergence of other characteristics as:

a. Their attention to the object.

b. The drive to relate more closely.

c. Their good feelings toward an object. [6]

Some education experts believe that the most effective way to generate interest in a new subject is to use the interests of students who have been there, also teachers also seek to establish new interests on students.[7]

As for some essential requirements for the emergence of interest include

1) The lessons will be of interest to students have to there is a connection between the lessons to real life.

2) Lessons are interesting to consider the students' personal interests.

3) The lesson will be more interesting for students if they are given the opportunity to be involved Interest in students will increase if he can see and experience that with the help of learned that he can achieve certain goals.

4) The lessons stimulates the interest and attention of students should provide an opportunity for participation and student involvement [8]

Interest in Learning of the students can be seen from a variety of things, namely:

1) Liking and interest in the things learned

2) The desire of students to learn

3) Attention to learn

4) The enthusiastic, participation and activeness in learning

From some of the above theory, the indicators that researchers use in this study are presented in Table 1 below.

Table 1. Indicator and aspects observed

\begin{tabular}{lll}
\hline No & Indicator & Aspects observed \\
\hline 1 & Feeling good & a. Always present in the implementation of learning (to class / \\
& & laboratory) \\
& b. Collect assignments on time \\
& c. Seemed excited about work and implementing learning with \\
& varied learning model
\end{tabular}

2 Attention

a. Attention to the teacher's explanation or show good attitude while attending in the class 


\section{Activity}

b. Having a good response in receiving materials (science)

In this study later will know the quality of interest in learning student towards the subjects of physical chemistry experiment. Physical Chemistry Experiment in department of chemistry education are conducted with seven title practicum. This practicum conducted using a scientific approach. The scientific approach in the view of chemistry is if there are questions to be asked, and the experiment should be carried out to find the answers to them. While the assumption of view of educational psychology scientific approach refers to a set of assumptions, attitudes, and procedures guide researchers in creating questions to investigate, produce evidence, and draw conclusions [9].

In a scientific approach carried out there are five important things done by students in menyelasikan a practicum. The five basic points: to observe, ask, gather information, associate and communicate. Implementing physical chemistry experiment using scientific approach is expected to provide motivation and raise students' interest in studying the material physical chemistry through practicum.

\section{Research Methods}

\subsection{Design Research}

This research was quantitative. Quantitative research methods attempt to maximize objectivity, replicability, and generalizibility of findings, and are typically interested in prediction. [9]

\subsection{Research Subjects}

Subjects in this study were students of department of chemistry education Universitas Islam Indonesia, the second half of 2015 forces amounted to 41 people.

\subsection{Research Instruments}

The research instrument used in this study is a questionnaire students interest in learning and documentation. Questionnaire interest in learning be made based on those existing indicators and aimed to assess adherence to the learning process with a scientific approach. Questionnaire or questionnaires (questionnaire) is a technique or way of collecting data indirectly (the researchers did not directly ask the respondent) using one type of questionnaire, the student questionnaire [10].

\subsection{Data Analysis Techniques}

Data analysis techniques in this study using qualitative descriptive analysis. 
Table 2. Scores Criteria and Students' Interest Category

\begin{tabular}{cccc}
\hline Criteria Curve Normal & Range Score & Percentage & Category \\
\hline $\mathrm{Mi}+1,5 . \mathrm{SDi} \leq \mathrm{X} \leq \mathrm{Mi}+3$. & $66 \leq \mathrm{X}<80$ & $84,4 \% \leq \mathrm{X} \leq 100 \%$ & Very Good \\
$\mathrm{SDi}$ & & & \\
$\mathrm{Mi}+$ 0. SDi $\leq \mathrm{X}<\mathrm{Mi}+1,5$. & $50 \leq \mathrm{X}<65$ & $71,1 \% \leq \mathrm{X}<84,4 \%$ & Good \\
$\mathrm{SDi}$ & & & \\
$\mathrm{Mi}-$ 1,5. SDi $\leq \mathrm{X}<\mathrm{M}+0 . \mathrm{SDi}$ & $35 \leq \mathrm{X}<49$ & $55,5 \% \leq \mathrm{X}<71,1 \%$ & Medium \\
$\mathrm{Mi}-$ 3. SDi $\leq \mathrm{X} \leq \mathrm{M}-1,5 . \mathrm{SDi}$ & $20 \leq \mathrm{X} \leq 35$ & Less \\
\hline
\end{tabular}

\section{Results and Discussion}

\subsection{Description of Data}

The results obtained in this study is in the form of questionnaire data from the learning interest of student learning in the laboratory with a scientific approach to the physical chemistry experiments at the Islamic University of Indonesia. Data collection was performed after the seven-time title practicum (meeting) fulfilled. Results obtained by the observers or researchers. The research was conducted to determine the interest of students towards subjects physical chemistry experiments, that consists of seven title practicum namely 1 ) thermochemical; 2) concentration of critical micelle ; 3) isotherm of adsorption ; 4) viscosity jetting power; 5) kinetics in alkaline solution; 6) the solubility as a function of temperature 7) photocatalyst. Results of the study are described in Table 2, and Figure 1 below.

Table 3. Interest categories of student learning Prodi Chemical Education in physical Chemistry experiments

\begin{tabular}{cccc}
\hline Category & Range Score & Frekuensi & $\begin{array}{c}\text { Percentage } \\
(\boldsymbol{\%})\end{array}$ \\
\hline Less & $20-34$ & 1 & 2,44 \\
Medium & $35-49$ & 18 & 43,90 \\
Good & $50-65$ & 20 & 48,78 \\
Very Good & $66-80$ & 2 & 4,88 \\
\hline Number of students & 41 & 100 \\
\hline
\end{tabular}




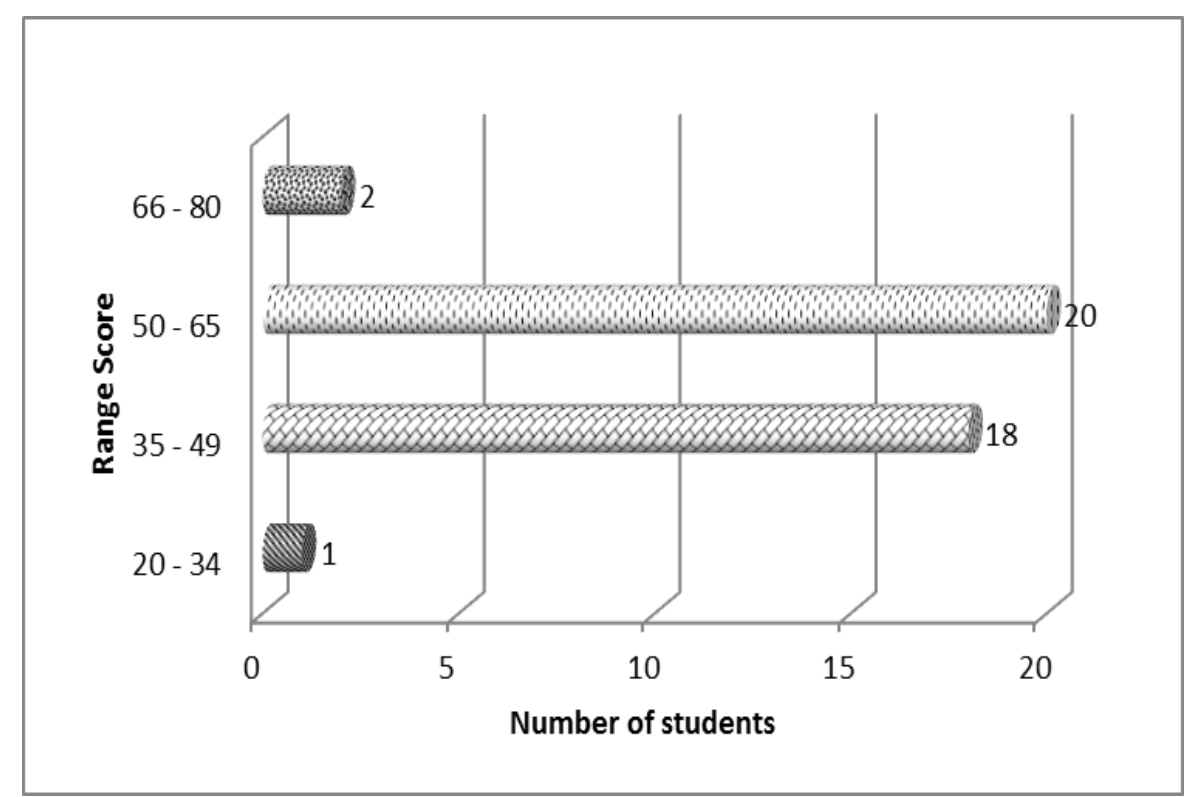

Figure 1. Number of Students and Categories of Interest Learning Students in Physical Chemistry experiment

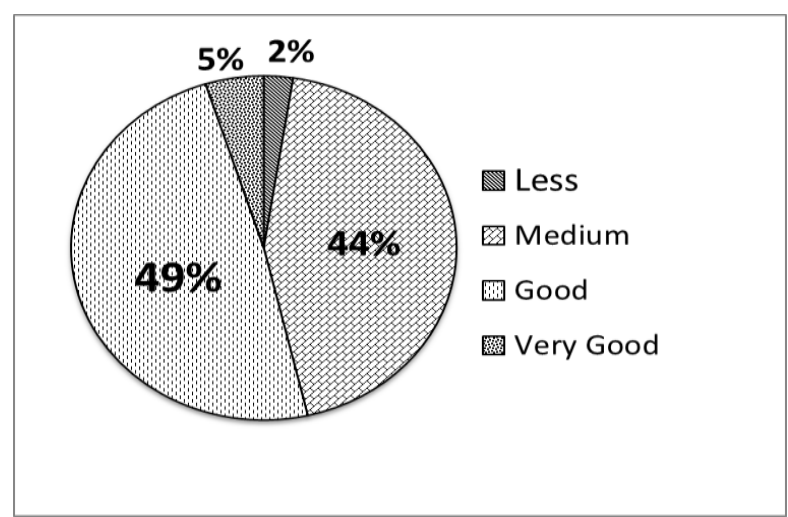

Figure 2. Pie Chart Trends of interest in Learning students in Physical ChemistryExperiments

Apart from the results of scoring the interest in learning can determine interest categories studied, the results of the analysis of interest in learning questionnaire scores can also be analyzed to get the achievement for each indicator of student interest. The result of score the interest in learning student scores can be seen in Table 4 and Figure 3 below.

Table 4. Average score of indicator of interest of student learning in physical chemistry experiments with a scientific approach

\begin{tabular}{clc}
\hline No & \multicolumn{1}{c}{ Indicator } & Mean score \\
\hline 1 & Feeling Good & $25 ., 9$ \\
2 & Attentiom & 17.8 \\
3 & Activity & 8,41 \\
\hline
\end{tabular}




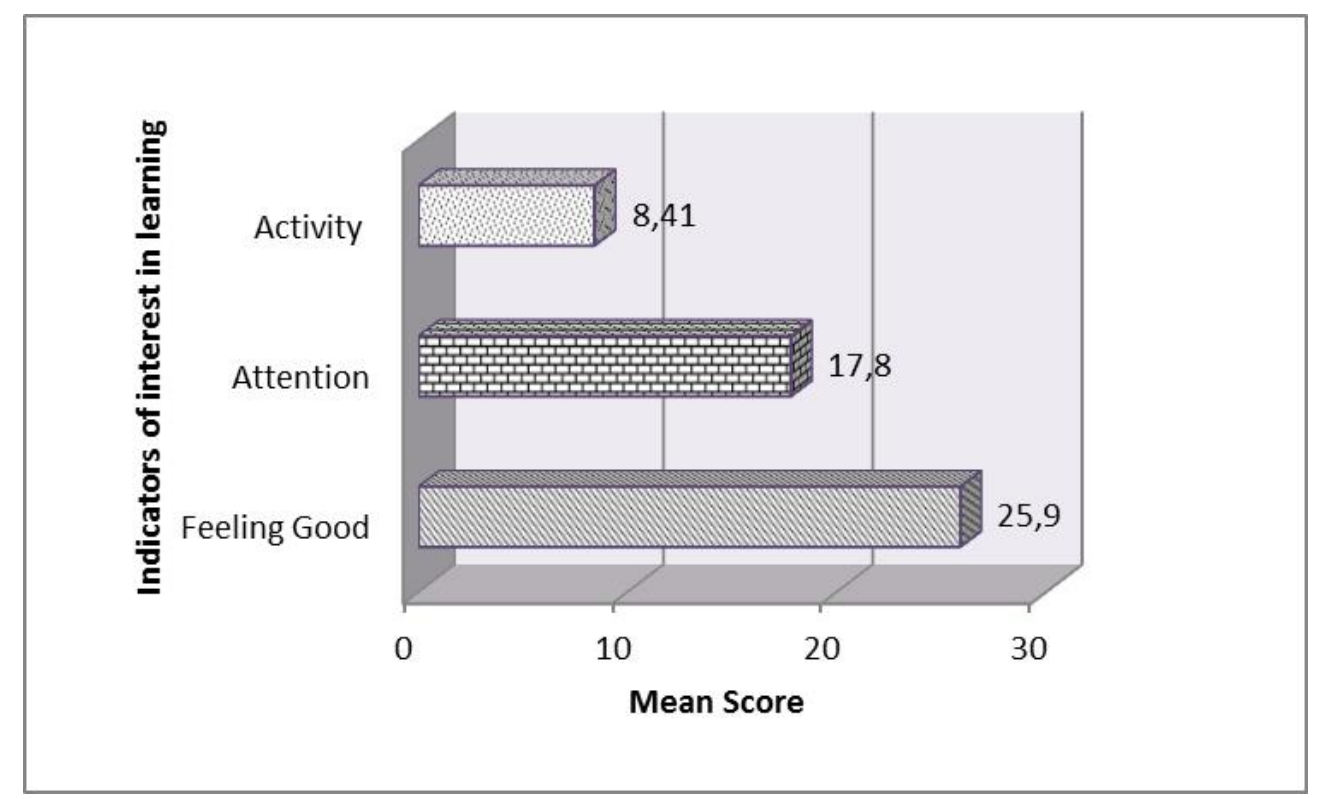

Figure 3. Average score of interest in students learning in physical chemistry experiment with a scientific approach

\section{Discussion}

In this study used data from questionnaires interest in learning students on physical chemistry experiments with the scientific approach. Questionnaire of interest in learning students is given after the implementation process with a physical chemistry lab scientific approach implemented for one semester. The calculation result obtained by descriptive analysis the average value obtained from the data (mean) $=51.83$, lowest score for students (minimum) $=20$, and the highest score obtained by the students $($ maximum $)=80$.

Interest in learning is something that accompanied the desire or ability deliberate attention and liveliness that eventually gave birth to a sense of fun in the form of a change in behavior or attitude of knowledge and skills. Interest in learning students can be seen on the feeling of likes and interests of students to the study, the need for students to learn, greater attention to the things they've learned, as well as active participation in the activities. This further reinforces the results of this study, namely the physical chemistry experiments, the result of the score of the questionnaire interest in learning shows that the highest percentage to score the learning interest of students in the physical chemistry experiments obtained in the category of "good" with the number of students who fall into this category numbered 20 people with a percentage of $48.78 \%$. It can be seen in Figure 2, where the highest percentage obtained in category good, and the percentage obtained in the lowest category of "less".

Student interest in this study using three indicators are feeling happy, attention and activity. Each indicator was developed by making some of the questions that appear on student interest questionnaire. The results of the study on an achievement of indicators can be seen in Table 4 and Figure 3 above. From these explanations indicate that the three indicators that sense of excitement, attention and activity, which has the highest scoring average is feeling good indicator of 25.9. Furthermore, the second highest at 
17.8 that attention and the latter is the activity of 8.41. From these data suggest that the results of questionnaire analysis the students' interest in physical chemistry experiments, students have a high interest in feelings of pleasure. In a learning process students should always be built learning motivation and interest to a study. Feeling good is one of evidence of student interest in the course or learning being implemented. Many things affect such as the use of appropriate learning models, vast opportunities provided by the teacher for students to actively and directly involved in teaching. This sort of thing will customarily provide its own spirit for students to maximize his ability. A lesson that can induce interest and attention of students should provide an opportunity for participation and student involvement.

The proper way to provide a great opportunity for students to engage in the learning process is the activity (the third indicator of students interest in learning). Implementation of activities would require of special attention of students to some of the supporting material and the explanation was given by the teacher. To that end, the second and third indicator in the interest in learning of this study also have an average score fairly high at 17.8 and 8.41. The scores obtained showed that the implementation of learning physical chemistry experiments courses able to foster student interest in learning. Implementation of learning using scientific approach was able to foster student interest in learning to be directly involved in learning activities. It is appropriate that expressed by Sardiman that interest in learning can help the smooth running of the learning process. Interest in learning can be raised in ways such as: 1) raise the existence of a necessity; 2) develop with the issue of the past; 3) provide an opportunity to get good results; 4) Using a variety of forms of teaching and atmosphere of each meeting should be familiar, cheerful, happy, courteous, and democratic. Interest in learning can also be seen from some of the attitudes of students, such as: 1) a sense of love and interest of students to learn things; 2) the need for students to learn; 3) greater attention to the things they've learned; and 4) active participation in learning activities. The interest has a tendency to grow. But interest someone (interest in learning) not only influenced by his interest in the content (material), but is also influenced by the knowledge and ability cognitive [11]. It is most important that the relation interest in student learning and quality of the learning experience associated with involvement in the learning process, pleasure and satisfaction, concentration or attention and activity $[12,13]$. All of these are included in the indicator interest in learning in this study that has been studied and analyzed. The use of learning approaches scientific able to build that knowledge, also able to increase interest in learning and curiosity of students. it is also clear from the research [14] that the inquiry learning (to build their knowledge) have an impact on students' motivation and interest in learning.

In conclusion, based on the results of the analysis showed that the students' interest in physical chemistry experiments with a scientific approach had an average of three indicators used are for a happy feeling of 25.9; 17.8 attention and activity of 8.41. The average overall score of 51.83. The analysis also showed that the students' interest in the department of chemistry education to physical chemistry experiments is the good category with the acquisition of a percentage of $48.78 \%$. 


\section{References}

[1] Gading IKt. "Pengaruh Pelatihan Kendali Diri dan Jenis Kelamin Terhadap Prilaku Prokrastinasi Akademik Siswa SMP", in Disertasi (Universitas Negeri Malang, Malang, 2014).

[2] Slameto. Belajar dan Faktor-Faktor Yang Mempengaruhinya, (Jakarta, Rineka Cipta, 2010).

[3] Akram MT, Ijaz A, and Ikhram H 2017 IJET. 7 pp 88-94

[4] Sardiman. Interaksi dan Motivasi Belajar Mengajar. (Jakarta : Rajawali Pers).

[5] Abdurrahman S, Didaktik Pendidikan Agama, (Jakarta, Bulan Bintang, 1976).

[6] Singer K, Membina Hasrat Belajar di Sekolah, (Bandung, Remadja Karya, 1973).

[7] Lincoln YS, and Guba EG.Naturalistic inquiry. Newbury Park, CA: Sage, (1985).

[8] Dantes N, Metodelogi Penelitian, (C.V Andi Offset, Yogyakarta, 2012).

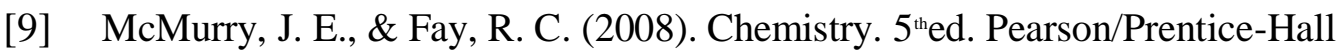

[10] Hockenbury DH, and Hockenbury SE. (2000). Psychology. $2^{\text {nd }}$ edition. NY: Worth Publisher

[11] Prenzel M, Die Wirkungsweise von Interesse. Ein Erkldrungsversuch aus padagogisch- 424 Interest and Self-Determination 425 Opladen, Germany: Westdeutscher Verlag.

[12] Prenzel. M. (1992). Selective persistence of interest. In K. A. Renninger, S. Hidi, \& A. Krapp (Eds.), The role of interest in learning and development (pp. 7198) (1988). Hillsdale, NJ.: Erlbaum.

[13] Schiefele U and Csikszentmihalyi M, The effect of interest on the quality of experience in classroom. Manuscript submitted for publication, (1990a).

[14] Schiefele U and Csikszentmihalyi M, Motivation, ability, and gender as factors in mathematics experience and achievement. Manuscript submitted for publication, (1990b).

[15] Wang PH, dkk. 2015. INTE, 174, pp 1292-1299 